\title{
フェロニッケルスラグを用いたコンクリートのポップアウト POPOUT OF CONCRETE INCORPORATING FERRO-NICKEL SLAGS
}

\author{
山本 泰 彦* ・秋 山 \\ 淳** \\ By Yasuhiko YAMAMOTO and Atsushi AKIYAMA
}

\begin{abstract}
Popout characteristics of concretes incorporating ferro-nickel slags as their fine aggregate were examined under various conditions for a long period of time. Of seven kinds of slags used in the test, three were found to cause the popout of concrete althouh the popout occured only when the concrete was stored under a moist condition. A particle of either white, whitish gray or reddish brown color was always observed to exist at the center of each popout. The X-ray diffraction analysis of the particle revealed that it was consisted of almost $100 \%$ brucite regardless of its color, indicating that the popout was caused by the hydration and the resulted expansion of some slag particles which were mainly composed of free $\mathrm{MgO}$. The free $\mathrm{MgO}$ was considered to have existed in the molten stage of slags and remained unhydrated during their chilling process at their drawing time from furnaces. Some effective means of producing stable slags were also discussed briefly.
\end{abstract}

Keywords: brucite, concrete, ferro-nickel slag, free $\mathrm{MgO}$, popout

\section{1. 序}

ポップアウト (popout) とは, 何らかの原因によっ て生じるコンクリート内部の圧力によって, コンクリー ト表面が局部的に押し出される現象であり,これによっ て脱落するコンクリート片は, 一般に薄い(高さが低い) 円錐形をしている. また, 内部圧力の発生は骨材の品質 に起因していることが多く，材質が弱く吸水率が大きい 骨材粒の内部水の凍結, アルカリ骨材反応, モンモリロ ナイトなどの粘土質鉱物の吸水膨張等がその原因になっ ている場合が多い.

著者らは, 砂状で排出されるフェロニッケルスラグ(以 下，単にスラグという）をコンクリート用細骨材として 活用するための使用方法や問題点に関する一連の研究を 行ってきているが, この過程で, コンクリートを $50^{\circ} \mathrm{C}$ の水中で養生した際に，2種類のスラグをそれぞれ単独 に用いたコンクリートの場合にもポップアウトが生ずる ことを観察した. また，X線マイクロアナライザーによ る分析結果を酸化物の形で表わして比較したところ,

* 正会員 工博 筑波大学助教授 構造工学系 (テ305 茨城県つくば市天王台 1-1-1)

** 正会員 工博 陸上自衛隊施設学校 （３12 茨城県勝田市滕倉 3433）
ポップアウトの原因となっていた粒子が $\mathrm{MgO}$ 含有量の 比較的多い粒子であることも判明し,これらに関しては, すでに報告しだ1).しかし，前報では，ポップアウトの 原因を十分に解明できる段階には至っていなかったの で,このような現象が認められたことの報告とポップア ウトの発生原因の推測を行うにとどめた. その後も, 著 者らは, ポップアウト性状やアルカリシリカ反応性を中 心としたスラグの使用上の問題点に関する研究を約 2 年 間継続して行ってきたが，この間に，i）前述の 2 種類 のほかに, 別の 1 種類のスラグもポップアウトの原因と なる粒子を含んでいること, ii ) ポップアウトの原因に なっている粒に別の色のものがあること, など新たな情 報が得られた。 また，分析方法に検討を加えた後に粒子 の鉱物組成を調べたところ，ポップアウトの原因を解明 するための有力なデータが得られたのである.

本文は，前報で示した試験結果の一部についても触れ ながら，スラグを用いたコンクリートのポップアウトの 発生状況について一般的に述べるとともに, 新たに得ら れた情報や試験結果も加えてポップアウトの発生原因の 究明を行った結果について論じたものである. 
表一1 フェロニッケルスラグの物理的性質

\begin{tabular}{|c|c|c|c|c|c|c|c|c|c|c|c|c|}
\hline \multicolumn{3}{|c|}{ フェロニッケルスラグ } & \multirow{2}{*}{$\begin{array}{l}\text { 表乾 } \\
\text { 比重 }\end{array}$} & \multirow{2}{*}{$\begin{array}{c}\text { 吸水率 } \\
\%\end{array}$} & \multirow{2}{*}{$\begin{array}{c}\text { 安定性 } \\
\text { 損失量 } \\
\%\end{array}$} & \multicolumn{6}{|c|}{ ふるいに留まる累計重量百分率、\% } & \multirow{2}{*}{$\mathrm{FM}$} \\
\hline 名称 & 種類 & 溶融妒 & & & & $5 \mathrm{~mm}$ & 2.5 & 1.2 & 0.6 & 0.3 & 0.15 & \\
\hline S 1 & 徐泠 & \multirow{3}{*}{ 電気妒 } & 3.06 & 1.82 & - & 100 & 94 & 82 & 57 & 38 & 26 & 2.03 \\
\hline $\begin{array}{c}\text { S } 2 \\
*\end{array}$ & 風碎 & & $\begin{array}{l}3.06 \\
2.94\end{array}$ & $\begin{array}{l}1.37 \\
0.85\end{array}$ & $\begin{array}{c}- \\
1.55\end{array}$ & 100 & 98 & 81 & 41 & 13 & 3 & 2.64 \\
\hline S 3 & \multirow{5}{*}{ 水碎 } & & 2.85 & 0.84 & 4.20 & 100 & 89 & 81 & 51 & 27 & 11 & 2.49 \\
\hline $\begin{array}{l}\text { S } 4 \\
*\end{array}$ & & $\begin{array}{c}\text { ロータリー } \\
\text { キルン }\end{array}$ & $\begin{array}{l}3.09 \\
3.05\end{array}$ & $\begin{array}{l}0.75 \\
0.99\end{array}$ & - & 100 & 93 & 70 & 47 & 25 & 9 & 2.56 \\
\hline $\begin{array}{l}\text { S } 5 \\
*\end{array}$ & & 溶鉱妒 & $\begin{array}{l}2.71 \\
2.74\end{array}$ & $\begin{array}{l}1.53 \\
1.35\end{array}$ & 1.87 & 100 & 95 & 77 & 44 & 16 & 7 & 2.62 \\
\hline $\begin{array}{c}\text { S } 6 \\
*\end{array}$ & & \multirow{2}{*}{ 電気妒 } & $\begin{array}{l}2.85 \\
2.86\end{array}$ & $\begin{array}{l}1.13 \\
0.91\end{array}$ & - & 100 & 94 & 75 & 52 & 21 & 3 & 2.66 \\
\hline $\begin{array}{l}\text { S } 7 \\
*\end{array}$ & & & $\begin{array}{l}3.00 \\
2.95\end{array}$ & $\begin{array}{l}0.96 \\
1.12\end{array}$ & $\frac{-}{1.88}$ & 100 & 100 & 79 & 31 & 13 & 4 & 2.74 \\
\hline
\end{tabular}

* 印のものは、 $38^{\circ} \mathrm{C}$ で保存したモルタル供試体の作成のみに用いた。

表一2 セメントの性覧

\begin{tabular}{|c|c|c|c|c|c|c|c|c|c|c|c|c|c|c|}
\hline \multirow{3}{*}{ 種類 } & \multirow{3}{*}{ 比重 } & \multirow{3}{*}{$\begin{array}{l}\text { 比表 } \\
\text { 面積 } \\
\mathrm{cm}^{2} / \mathrm{g}\end{array}$} & \multicolumn{2}{|c|}{$\begin{array}{c}\text { 㿅结 } \\
\text { (時-分) }\end{array}$} & \multirow{2}{*}{\multicolumn{3}{|c|}{$\begin{array}{c}\text { 圧縮強さ } \\
\mathrm{kgf} / \mathrm{cm}^{2}\end{array}$}} & \multirow{2}{*}{\multicolumn{7}{|c|}{ 化学成 分、 \% }} \\
\hline & & & \multirow{2}{*}{$\begin{array}{l}\text { 始発 } \\
\text { 時間 }\end{array}$} & \multirow{2}{*}{$\begin{array}{l}\text { 終結 } \\
\text { 時間 }\end{array}$} & & & & & & & & & & \\
\hline & & & & & 3日 & 7日 & 28日 & $\mathrm{SiO}_{2}$ & $\mathrm{Al}_{2} \mathrm{O}_{3}$ & $\mathrm{Fe}_{2} \mathrm{O}_{3}$ & $\mathrm{Ca} 0$ & Mg0 & $\mathrm{SO}_{3}$ & $\mathrm{Na}_{2} \mathrm{O}$ eq. \\
\hline-1 & 3.16 & 3240 & $2-28$ & $3-31$ & 141 & 230 & 411 & 22.1 & 5.5 & 3.0 & 64.9 & 1.4 & 1.8 & 0.57 \\
\hline$c-2$ & 3.16 & 3210 & $2-32$ & 3-38 & 142 & 232 & 411 & 22.2 & 5.4 & 3.1 & 65.1 & 1.2 & 1.9 & 0.66 \\
\hline$c-3$ & 3.15 & 3430 & $2-30$ & $3-28$ & 135 & 230 & 378 & 22.3 & 5.1 & 3.0 & 63.2 & 1.7 & 1.9 & 1.03 \\
\hline
\end{tabular}

\section{2. 使用材料}

この研究で対象としているスラグの物理的性質は表一 1 のようであり，これらの呼称等は前報 ${ }^{1)}$ と同じである. コンクリート供試体および $20^{\circ} \mathrm{C}$ の水中に長期間保存し たモルタル供試体の作成には，表一1に粒度の示されて いるスラグを十分に吸水させた後に用いた。これに対し， $38^{\circ} \mathrm{C}$ の条件下に保存したモルタル供試体の作成には, 表一1に物性值が $2 つ$ 示されているものの場合には下段 のスラグを用い, ASTM C 227 (モルタルバー法) に規 定されている粒度にあらかじめ調整しておいたものを絶 乾状態で用いた。これは， $38^{\circ} \mathrm{C}$ に保存したモルタル供 試体の場合はスラグのアルカリシリカ反応性を調べる目 的も兼ねて試験を行った理由による.

セメントには, アルカリ量が異なる 3 種類の普通ポル トランドセメントを用いた。これらのセメントの $\mathrm{Na}_{2} \mathrm{O}$ 等価アルカリ量は $0.57,0.66$ および $1.03 \%$ であった. セメントの試験成績表は表一2 に示した.

粗骨材には鬼怒川産の玉石砕石（最大寸法 $=25 \mathrm{~mm}$, 比重 $=2.60$, 吸水率 $=1.30 \%$, 実積率 $=58.8 \%$, 粗粒 率=7.19）を表乾状態で用い， AE 剤には樹脂系のもの を使用した。

\section{3. 配合および試験方法}

\section{（1）コンクリートによる試験}

コンクリートの配合は，水セメント比を $50 \%$ とし， スランプおよび空気量をそれぞれ $(8.0 \pm 0.5) \mathrm{cm}$ およ び (4.5〜5.0) \% と一定にした.この配合のコンクリー トにより $\phi 10 \times 20 \mathrm{~cm}$ の円柱供試体を作成し，材令 2 日 に脱型した．脱型後は，供試体を材令 7 日まで $20^{\circ} \mathrm{C}$ の 水中で養生した後, (1) $20^{\circ} \mathrm{C}$ の水中, (2) $50^{\circ} \mathrm{C}$ の水中, (3) 自然の条件にさらされる屋外 (筑波大学構内), に静置 しておき, 約 3 年半にわたってその表面の変化を観察し た.この試験では, 溶融炉が異なる 3 種類の水砕 ( S 4, $\mathrm{S} 5, \mathrm{~S} 7)$ と風砕（S2）を対象として，それぞれの条 件に対し供試体を 2 本ずつ作成した。 ただし，S4を用 いたコンクリートについては, $50^{\circ} \mathrm{C}$ の試験槽の容量に 制限があったこと, 屋外より水中の方がポップアウトの 生じる可能性が高いと考えられたこと，などの理由で, $20^{\circ} \mathrm{C}$ の水中でのみ試験した. コンクリートの作成には, C-1のセメントを用いた.

\section{（2）モルタルによる試験}

常温でのポップアウト性状をモルタル供試体で調べた 試験では，すべてのスラグを試験の対象とし，モルタル 


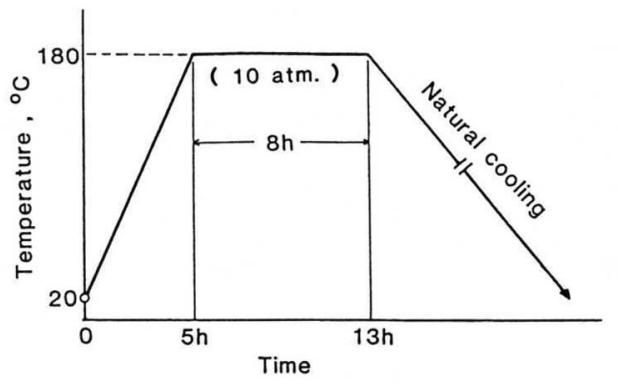

図一1 オートクレーブ養生槽内の温度履歴

の水セメント比は $50 \%$, 砂セメント比は体積比で 3.65 とした．供試体の寸法は $4 \times 4 \times 16 \mathrm{~cm}$ であり，これら の作成にも C-1 のセメントを使用した，供試体の脱型 は材令 1 日に行い, その後, 供試体を $20^{\circ} \mathrm{C}$ の水中に 3 年間静置して, その表面に異常が生じるか否かを観察し た.

上記のモルタル供試体には, その水中養生終了直後に, さらに $180^{\circ} \mathrm{C}$ のオートクレーブ養生（10 気圧）を 8 時 間施した.この試験をはじめとして, 本研究で採用した オートクレーブ養生の養生槽内の温度履歴は図一1 に示 すようであった。

モルタル供試体を比較的高温の条件下に保存した場合 のポップアウト性状については, スラグのアルカリシリ カ反応性と同時に調べることにした。このため, 供試体 はASTM C 227 (モルタルバー法) に従って作成した. また, 供試体の保存条件もモルタルバー法と同じであっ て，温度が $38^{\circ} \mathrm{C}$ で湿度がほぼ $100 \% \mathrm{RH}$ となるように 調整した恒温恒湿槽内に供試体 $(25 \times 25 \times 285 \mathrm{~mm})$ を 静置した. ただし, 供試体の保存は, アルカリ骨材反応 の試験に必要な期間（6 か月）を超えて 15 か月間行い, この間におけるポップアウトの発生の有無を調べた.な お,この試験のモルタル供試体には, アルカリ量の異な る C-1, C-2 および C-3 のセメントをそれぞれ単独で 使用したものだけでなく, $\mathrm{NaOH}$ の添加によってセメ ント量に対する $\mathrm{Na}_{2} \mathrm{O}$ 等価アルカリ量を最大 $2 \%$ にま で増加させたものも含まれている.

\section{（３） ポップアウトの原因粒子のX線回折分析}

ポップアウトの原因となっていた粒子の組成分析に は, 粉末 X 線回折法を用いた. 回折には $\mathrm{Cu} の \mathrm{~K} \alpha$ 線を 用い, $30 \mathrm{kV}, 15 \mathrm{~mA}$ で分析した.

分析用試料の採取にあたっては，ポップアウトの原因 となっていた粒子の周辺にあるセメントペーストの混入 を防ぐために，ポップアウト部を顕微鏡下に置き，針を 用いて粒子の内部から少しずつ試料をかきとった.この ようにして採取できた試料は，一般にはきわめて微量で あり，そのまま通常のような粉末 X 線回折を行うことは
不可能であった. そこで, 次のような方法により分析用 試料を作成した。 まず, 採取した試料を乳鉢の中で微粉 砕し,これを少量のエタノール中に懸濁させた. 次いで, この懸濁液を無反射石英板の上に約 $15 \times 20 \mathrm{~mm}$ の広さ に塗布した後, エタノールを完全に蒸発させた.このよ うにして作成した試料を石英板ごとX線回折装置の試料 台に取り付け, 石英板の表面に付着させた粉末試料の組 成分析を行った.

\section{4. ポップァウトの発生状況と特徵}

\section{（1） ポップアウトの形態}

スラグを用いたコンクリートのポップアウトは, 骨材 粒の膨張に起因して生ずるポップアウトの典型的な形態 のものであることが認められ，ポップアウト部のほぼ中 央にはポップアウトの原因となった骨材粒子 (以後, 単 にポップアウト粒子という)が例外なく存在していた(写 真-1).

ポップアウト粒子の粒径は約 1〜 $5 \mathrm{~mm}$ の範囲にあり, その位置は最も梁いものでも供試体の表面から約 10 $\mathrm{mm}$ であった. また, 剥離したモルタル片（コンクリー

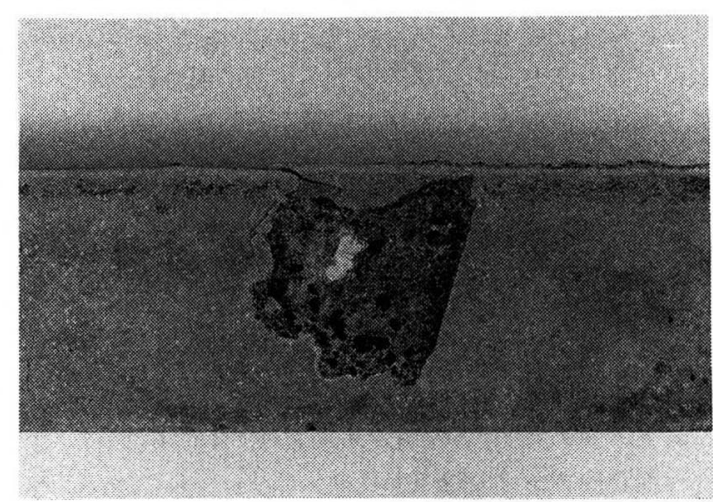

写真一1 モルタル供試体のポップァウト (中央部に灰白色の粒子がある)

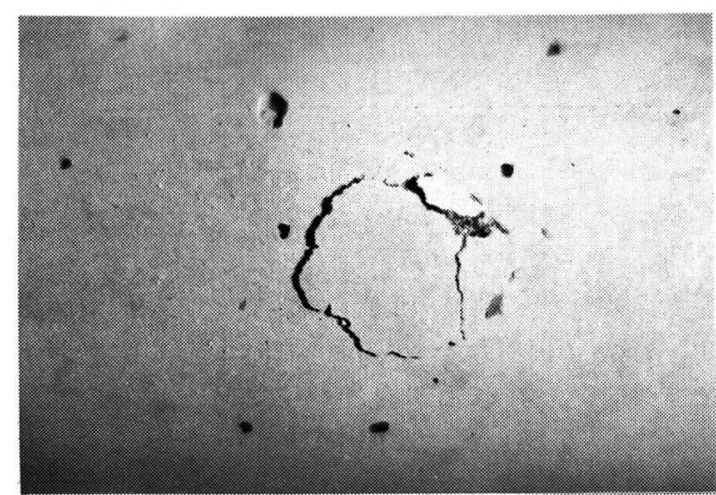

写真一2 ポップァゥトによるコンクリートの膨張ひびわれ 
ト片）の大きさは，ポップアウト粒子の粒径と供試体表 面から粒子表面までの距離に比例して大きくなる傾向に あった。たとえば，最も大きなポップアウトは深さ約 $10 \mathrm{~mm}$ の位置にあった粒径 $5 \mathrm{~mm}$ 程度の粒子の膨張に よって生じており,この程度のポップアウトが生じた場 合におけるコンクリートの損傷表面積は $5 \sim 7 \mathrm{~cm}^{2}$ 程度 であった、ただし，本研究ではスラグを細骨材として用 いているので, ポップアウト片の大きさは比較的小さい ものが多く, 特に表面から約 $1 \mathrm{~mm}$ 以内にある小さな骨 材粒子がポップアウトの原因となっていた場合には骨材 粒の頭部にある薄いペースト膜が少々剥離する程度のも のも認められた。なお，大きなポップアウトが生じる部 分には，その前の段階に写真一2のような膨張ひびわれ が現われており,このひびわれの奥に発生した膨張圧(こ の場合は骨材粒の膨張による圧力）がポップアウトの原 因となっていることを端的に示していた。

\section{（2）ポップアウトが生じた保存条件}

$20^{\circ} \mathrm{C}$ の水中や屋外の自然環境下に 3 年以上保存した 供試体の場合には，いずれのスラグを用いても，ポップ アウトは全く認められなかった。これに対し，供試体を 乾燥させない状態に保ちながら高い温度条件下で保存し た場合には, ポップアウトが発生した。この場合, 保存 温度が高いほど，ポップアウトが早期に現われ，ポップ アウトを生じさせるスラグの種類が多くなる傾向にあっ た。すなわち，スラグのアルカリシリカ反応性の試験も 兼ねて $38^{\circ} \mathrm{C}$ で保存した場合には，S7およびこれを $1100^{\circ} \mathrm{C}$ で再加熱処理したスラグを用いた供試体のごく 一部に保存期間 9 12 か月の時点でポップアウトが観察 されたに過ぎなかった。これに対し， $50^{\circ} \mathrm{C}$ の温水中に 保存した場合には，この試験に用いた 3 種類（S2， $\mathrm{S} 5, \mathrm{~S} 7)$ のうち，2 種類のスラグ ( S 2 および S 7) が 保存期間約 3 か月の時点よりコンクリートにポップアウ 卜を生じさせたのである．また， $20^{\circ} \mathrm{C}$ の水中に 3 年間 保存しても全く異常の認められなかったモルタルを $180^{\circ} \mathrm{C}$ で 8 時間オートクレーブ養生した場合には，上記 のS 2 とS7 を用いた供試体に加えて，S4 用いた供 試体にもポップアウトが生じていた。これらの結果は, ポップアウト粒子の膨張の原因に温度依存型の現象，た とえばArrhenius の反応速度式に従う化学反応，が関与 している可能性が強いことを示すものと思われる.

\section{（3） ポップアウトの数}

ポップアウトの数（頻度）に関しては，一般には， $\phi$ $10 \times 20 \mathrm{~cm}$ の円柱供試体の表面 $\left(785 \mathrm{~cm}^{2}\right)$ に 1 - 2 所 であり，多い場合でも3〜4 か所程度であった。また， 同じバッチから作成した供試体でもポップアウトの認め られないものもあった. $25 \times 25 \times 285 \mathrm{~mm}$ のモルタル供 試体（表面積＝約 $300 \mathrm{~cm}^{2}$ ）の場合には，ポップアウト
表一3 スラグの主要な化学組成

\begin{tabular}{c|c|c|c|c|c|c}
\hline \multicolumn{2}{c|}{} & \multicolumn{5}{c}{ スラグ } \\
\hline \multirow{2}{*}{ ボッフアウト } & 名称 & $\mathrm{Si}_{2}$ & $\mathrm{Mg} 0$ & $\mathrm{Ca} 0$ & $\mathrm{Al}_{2} 0_{3}$ & $\mathrm{Fe} 0$ \\
\hline \multirow{2}{*}{ 有 } & $\mathrm{S} \mathrm{2}$ & 53.2 & 34.4 & 1.5 & 2.9 & 6.2 \\
& $\mathrm{~S} \mathrm{4}$ & 54.1 & 28.4 & 5.5 & 2.4 & 7.7 \\
& $\mathrm{~S} \mathrm{7}$ & 52.2 & 33.7 & 0.9 & 1.5 & 9.0 \\
\hline \multirow{2}{*}{ 無 } & $\mathrm{S}$ 1, S 3 & $50 \sim 56$ & $26 \sim 37$ & $0.2 \sim 14$ & $1.2 \sim 3.7$ & $4.4 \sim 6.4$ \\
& $\mathrm{~S} 5$, S 6 & & & & & \\
\hline
\end{tabular}

は通常 1 か所のみに生じていた。これらの結果から判断 すると，元のスラグ中に存在するごく一部の粒子がポッ プアウトを生じさせたものと思われる.

\section{（4）ポップアウト粒子の特徵}

ポップアウト粒子は，その色が健全な粒子の色と比べ て著しく異なっているところに大きな特徴があり，この 色の相違によってコンクリートあるいはモルタルのポッ プアウトの原因となっていた粒子を容易に識別すること ができた。すすなわち，ポップアウト粒子の色は，スラグ の種類にかかわらず，いずれも白色，灰白色あるいは赤 褐色であり, 元の急冷スラグの色（黒色, 黒灰色, 褐色 あるいは暗褐色）之著しく相違していた。これらの色の 粒子のうち，白色および灰白色のポップアウト粒子は, これらを粒のまま摘出できないほど軟化していた.一方, 赤褐色の粒子は，粒の状態での摘出が容易にできる程度 の硬さを保有していた.

\section{（5）元のスラグの平均的な化学組成}

この研究では, わが国で排出されているすべてのスラ グ（7 種類）を対象として試験を行ったが，前記のよう に, これらのうち $\mathrm{S} 2, \mathrm{~S} 4$ および S 7 の 3 種類のスラグ を用いた場合にのみポップアウトが認められた。表一3 は，コンクリートにポップアウトを生じさせたこれらの スラグの主要な化学組成をその他のスラグの組成と比較 して示したものである.この表より，ポップアウトを生 じさせたスラグの $\mathrm{FeO}$ 含有量がやや多い傾向は認めら れるものの, 全般的には元のスラグの化学組成にはほと んど差がないといえると思われる.

\section{5. ポップアウトの発生原因に関する検討}

上述したポップアウトの状況から判断すると，スラグ を用いたコンクリートのポップアウトは，スラグ中の一 部の粒子がコンクリート中で膨張したことによって生じ たと考えて誤りはないといえる。このような骨材粒の膨 張が生じる原因としては，1．で述べたような各種の要 因があるが，S7 をはじめ一部の種類のスラグがアルカ リシリカ反応性を有する ${ }^{1,2)}$ ことを考慮すると，この反 応による影響も考えられる。しかし，前報)でも述べた ように, ポップアウト粒子の周辺にはゲルの浸出, 反応 リムの形成などのアルカリシリカ反応に特有な徵候は全 
く認められなかった. また, その後の著者らの研究 ${ }^{2)} に$ より，ポップアウトを生じさせた S 2, S 4, および S 7 を再加熱処理したスラグは, ガラス質をほとんど含まず, アルカリシリカ反応を起こさない種類のスラグであるこ とが明らかにされたのである.さらに，モルタルによる 試験では, アルカリ量を広範に変化させたが, ポップア ウトの発生状況はアルカリ量に全く関係がなかった.こ れらの結果は, スラグ粒子のアルカリシリカ反応がポッ プアウトの発生原因となっている可能性をほぼ完全に否 定するものと思われる.

フェロニッケルの製造工程やスラグの物理的性質を考 慮すると, 平均的なスラグ粒子がコンクリート中におい てポップアウトを生じさせるほどの吸水膨張を起こすと は考えられない. しかし，使用前のスラグの母集団を注 意深く調べたところ, 赤褐色の粒は皆無であったが,ポッ プアウト粒子の色に比較的近い白色および死白色の粒は ごくわずかながら存在しており，これらの粒の存在が ポップアウトの原因となったとも考えられた.この点を 確認するために, 白色および灰白色の粒をはじめ, スラ グの母集団の中から各種の色の粒を数多く拾い出し, こ れらを表面部（粒がほぼ隠れる程度の深さ）に埋め込ん だペースト供試体を造って, $50^{\circ} \mathrm{C}$ の水中に保存しなが らポップアウトの発生の有無を観察した. しかしながら, 保存期間 1 年以上を経過しても異常は認められず,これ らをさらに $180^{\circ} \mathrm{C}$ で 8 時間オートクレーブ養生しても ポップアウトは全く発生しなかった. また, 元のスラグ 中に存在していた白色および灰白色の粒はきわめて緻密 で硬く, その後に行ったX線マイクロアナライザーによ る分析では，これらの粒の組成はそのほぼ $100 \%$ がシ リカであることが判明したのである。これらの結果から 判断すれば, ポップアウトが元のスラグ中にわずかに存 在する特別な色をした粒子の物理的な吸水膨張によって 生じた可能性はほとんどなく, 前述したポップアウト粒
子の独特な色は何らかの原因によるスラグ粒子の変質の 結果として生じたものと考えざるを得ないのである.そ こで, 以後は, ポップアウト粒子の組成分析を行い, そ の結果をもとにポップアウトの原因究明を行うことにし た.

ポップアウト粒子の中央部の成分を X 線マイクロアナ ライザーによって点分析した結果の一例を図一 2 に示 す. 前報 ${ }^{1)}$ では, このような原子の相対的な量の形で得 られた分析結果を酸化物の相対的な量の形に換算して表 わした最終結果を示し, セメント水和物の混入の影響が 少ないと考えられる試料（粒状のまま摘出できたもの） の場合には $\mathrm{MgO}$ に換算した量が約 $80 \%$ にも達してい たことを考慮して, スラグ中に $\mathrm{MgO}$ を含む粒子が存在 している可能性があり,これがポップアウトの発生原因 となった公算が高いと考えられることを指摘した.なお， 写真一3は, モルタルが付着していたポップアウト粒子 の Ca および $\mathrm{Mg}$ に関する面分析の結果を示したもので あるが,この図からもポップアウト粒子が $\mathrm{Mg}$ を相当

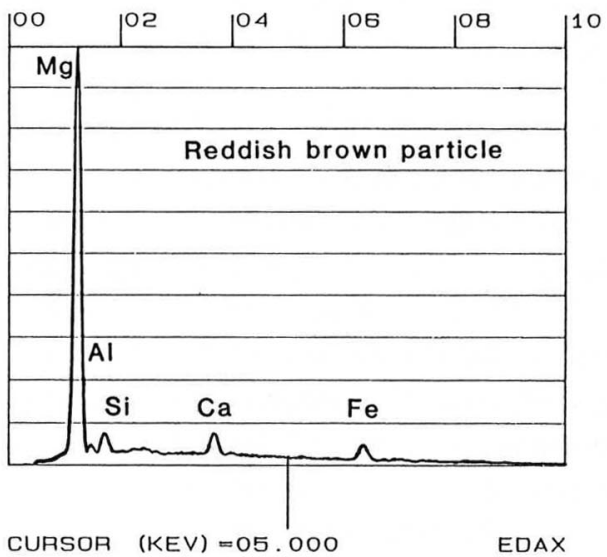

図一2 X線マイクロアナライザーによるポップアウト粒子中央 部の点分析結果
Magnesium $(\mathrm{Mg})$

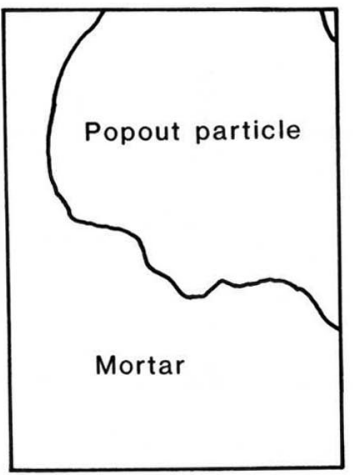

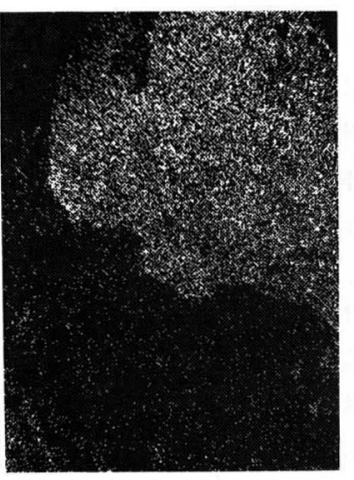

Calcium (Ca)

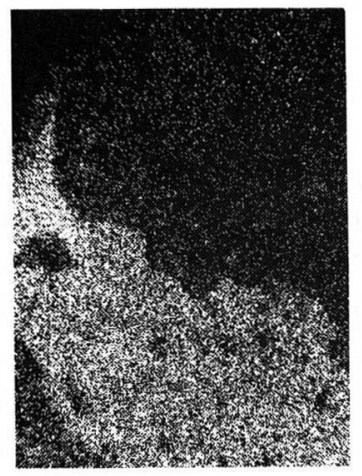

写真一3 X 線マイクロアナライザーによるポップアウト部の面分析結果 （白い点が多いほど, 各原子が多く含まれていることを示す） 
に含んでいるものであることが認められる.しかしなが ら, 白色系の軟化したポップアウト粒子の場合には, 異 物の混入の影響が大きいこともあり, $\mathrm{MgO}$ の量は 40 \% 程度に過ぎなかった. また, X線マイクロアナライ ザーによる分析では，試料に含まれる比較的重い原子の 相対的な量に関する情報は得られるが，試料を構成する 物質 (本研究の場合は, 鉱物) そのものを直接的に明ら かにすることができない難点がある．さらに，この方法 によって点分析を行っても, 分析点の周辺部や深さ方向 に存在する原子の影響が分析結果にかなり入ってくるこ とが多い。これらの諸点を考慮し, 前報ではポップアウ トの原因に関しては，これを上記のように推測するにと どめたのである.

図一3 は, コンクリートあるいはモルタル中に存在す るポップアウト粒子から注意深く採取した微量の純粋な 試料をX 線回折法で分析した結果を示したものである. 分析した試料は, 合計 6 個の異なる試料 (白色粒子 3 個, 赤褐色粒子 2 個，灰白色粒子 1 個）であり，これらの試 料には，ポップアウトを生じさせたすべての種類のスラ グ（S2，S4，S7 および S7 の熱処理スラグ）のポッ プアウト粒子が含まれている. 図一3を参照すると, ポッ プアウト粒子のX $\mathrm{X}$ 線回折図は前報 ${ }^{1), 2)}$ に示した元のスラ グの回折図とは全く異なっており，いずれの色のポップ アウト粒子の場合にも, $\mathrm{Mg}(\mathrm{OH})_{2}$ のピークが明瞭に認 められる. しかも, セメント水和物の混入の影響と考え られる小さなピークが存在しているものもあるが, いず れの試料の場合にも $\mathrm{Mg}(\mathrm{OH})_{2}$ のピークのみが主要なも のとなっている.これらの結果は，いずれの色のポップ アウト粒子もブルーサイト $\left[\mathrm{Mg}(\mathrm{OH})_{2}\right]$ を主な組成とす るものであることを示すものと考えられるのであって， スラグ中に遊離の $\mathrm{MgO}$ を含む粒子が存在し, これがコ ンクリート中で次のような反応を起こしたことがポップ アウトの発生原因であると考えた前報の推測が正しかっ たことを証明するものと考えられる.

$$
\mathrm{MgO}+\mathrm{H}_{2} \mathrm{O} \rightarrow \mathrm{Mg}(\mathrm{OH})_{2}
$$

また，図一3には $\mathrm{Mg}(\mathrm{OH})_{2}$ 以外の鉱物のピークがほと んど認められないこと，ポップアウト粒子は粒全体が一 様に変色あるいは変質していたこと, 等を考慮すると, 使用前の各ポップアウト粒子はそのほぼ全体がペリクレ イス $[\mathrm{MgO}]$ から成っていたものと考えられる.

純粋な $\mathrm{Mg}(\mathrm{OH})_{2}$ の色は白色であるので, 白色のポッ プアウト粒子の場合は，その大部分がほぼ純粋な $\mathrm{Mg}$ $(\mathrm{OH})_{2}$ から成っていたと考えることができる.これに対 し, 白色以外のポップアウト粒子の場合には, 上記のよ うに $\mathrm{Mg}(\mathrm{OH})_{2}$ が主な組成であったにもかかわらず，前 述したような灰白色あるいは赤褐色を呈していたことは 一見不合理のように思われる. しかし，この色の相違に
関しては，ポップアウト粒子中に微量に存在していても 粒子を灰白色あるいは赤褐色に変色させ得るスラグ成分 の混入の影響と考えられる．具体的には，スラグ中の鉄 分の影響と考えられ，灭白色のものは水酸化第一鉄 $\left[\mathrm{Fe}(\mathrm{OH})_{2}\right]$ を,赤褐色のものは水酸化第二鉄 $\left[\mathrm{Fe}(\mathrm{OH})_{3}\right]$ を微量ながら含んでいた影響と思われる.

以上より，スラグを用いたコンクリートのポップアウ 卜は，遊離の $\mathrm{MgO}$ を主成分とする粒子がスラグ中に存
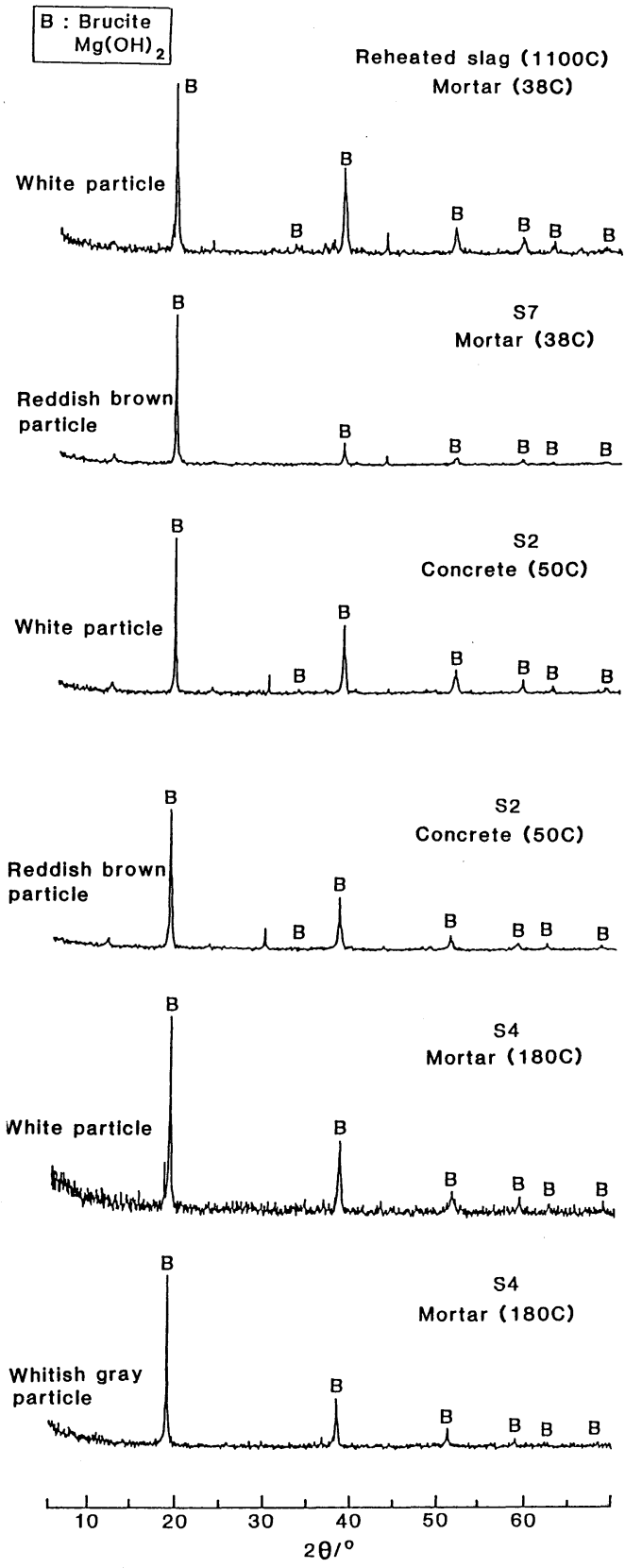

図一3 ポップアウト粒子の粉末 X 線回折試験結果 
在し，これが水と反応して膨張することによって生じた ものであることが明らかになった。このような遊離の $\mathrm{MgO}$ がスラグ中に存在していた理由に関しては，フェ ロニッケルスラグの製造時における溶融炉の温度 (1 600

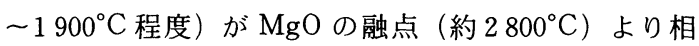
当に低いこと，一般には溶融スラグは溶融炬からの排出 時に急冷されていること, などを考虑すると, ニッケル 鉱石の中に遊離して存在していた $\mathrm{MgO}$ の一部が溶融炉 内においても融解せずにそのまま残存していたことが考 えられる. また，溶融スラグ中の成分の偏りにより夜相 中に $\mathrm{MgO}$ が析出した可能性も考えられる。ここで重要 なことは, これらの理由のいずれであっても, ポップア ウトの原因となっていた $\mathrm{MgO}$ が溶融スラグ中に遊離し て存在していたと考えられることである.これが事実と すれば, 本研究でポップアウトを発生させなかった種類 のスラグの場合にも, 溶融スラグの段階では, 遊離の $\mathrm{MgO}$ を含んでいた可能性がきわめて高いといえよう. しかし，実際には，4. でも述べたように，7種類のうち の 3 種類のスラグを用いた場合にのみポップアウトが認 められたに過ぎなかった. また, ポップアウトの発生数 から判断すると，ポップアウトを生じさせる粒の混入割 合はごくわずかであると考えられるのである. 後者につ いては,これをさらに確認するために, ポップアウトを 発生させた種類のスラグ（S2, S4 および S7）を約 $500 \mathrm{~g}$ ずつ採取して, これらを 2 日間吸水させた後, $180^{\circ} \mathrm{C}$ で 8 時間オートクレーブ養生してみたが, この試 験では粒子の変色あるいは変質は全く観察されなかっ た.これらの結果は, 溶融炬からの排出時には, いずれ の種類のスラグの場合にも遊離の $\mathrm{MgO}$ が含まれている 可能性があるにもかかわらず, 実際には, ポップアウト の原因となる粒子は限られた種類のスラグに，しかも，

微量に含まれていたにすぎないことを示している．この ように，スラグの種類によって遊離の $\mathrm{MgO}$ を含むもの と含まないものとがあり, $\mathrm{MgO}$ を含むものでもその量 が微量であった理由については, 次のように考えること ができる.

前記の式 (1) で表わされる $\mathrm{MgO}$ の水和反応は, 常 温においても比較的速やかに生じるが, 温度が高いほよ゙ 速く進む. 養生温度が高い場合ほど早期にポップアウト が認められた [4. ( 2 ) 参照] のは, この理由によると 考えられる. したがって，一般には，溶融スラグを水砕 する段階で, 溶融スラグ中に存在する遊離の $\mathrm{MgO}$ のほ とんゼが安定した水和物に変化すると考えられる. しか しながら, 水砕の際に水亡直接接触し得ない $\mathrm{MgO}$ が微 量ながらも残存する可能性が全くないとはいいきれない のであって, 特に溶融炉から排出されてくるスラグ流の 初めの部分などのように温度が低く粘性の高い溶融スラ
グを水砕する場合などにはこの種の $\mathrm{MgO}$ が含まれてい る可能性が高いと思われる. ただし, この時点で残存す る遊離の $\mathrm{MgO}$ は, 水砕後に高温で多湿の状態に保たれ る時間がある程度確保されれば，その中心部まで安定な $\mathrm{Mg}(\mathrm{OH})_{2}$ に変化すると思われる. しかし, 水砕後に水 槽中に放出冷却されるまでの時間が非常に短い場合に は, 一部の $\mathrm{MgO}$ が遊離したままの状態で残る可能性が 大きくなると考えられる. 本研究で対象とした水砕スラ グS 4 およびS 7 の場合は, これらの溶融スラグの排出, 水砕あるいは冷却の工程の中で, 上述したような遊離の $\mathrm{MgO}$ が残存しやすい条件が存在したためにポップアウ 卜を発生させる粒子を含んでいたものと思われる.また, $\mathrm{S} 2$ は, 風砕であるので, 水と接触する機会がなく, 溶 融スラグ中の遊離の $\mathrm{MgO}$ をそのまま含んでいたために ポップアウトを生じさせたものと考えることができる.

上記の考え方に基づいて，ポップアウトを発生させな いスラグを製造するための方策を考えてみると, 水砕ス ラグの場合には，i）溶融スラグの流れの初めの部分を 廃棄する, ii ) 水砕後, 水槽中で急冷するまでの時間を 長く採る（スラグを高温多湿に保つ時間をできるだけ長 くする), 等が有効と思われる. 一方, 風砕スラグの場 合には, 風砕した後にも赤熱した状態にあるので, 赤み が消えて適当な温度になった時期にスラグのほぼ全量に 水分が行き渡る程度に散水し, その後, 適当な時間高温 多湿な状態に保てば安定したスラグが得られるものと思 われる.なお, 前記の式 (1) の反応が常温でも比較的 速く生じることを考慮すると, 屋外に長期間放置してお いたものほどポップアウトを発生させる可能性が小さく なることも予想される. ポップアウトの発生を防ぐため のこれらの方策に関しては, 現時点でも相当に効果のあ るものと思われるが, 実際の個々の効果については今後 さらに確認していく必要がある.

\section{6. 結 論}

スラグを用いたコンクリートおよびモルタルに認めら れたポップアウトの発生状況を調べるとともに, ポップ アウトの発生原因について検討した，実験の範囲内で， 次のことがいえると思われる.

（1） スラグコンクリートのポップアウトによる剝離 部の中央には, 白色, 灰白色, あるいは赤褐色の粒子が 必ず存在する. 剶離部に存在するこれらの粒子は, いず れも $\mathrm{Mg}(\mathrm{OH})_{2}$ を主な組成とするものであり, 特に, 白 色の粒は純度の高い $\mathrm{Mg}(\mathrm{OH})_{2}$ から成っていると考えら れる.これに対し, 灰白色および赤褐色の粒は, それぞ れ，水酸化第一鉄および水酸化第二鉄を微量ながら含ん だ粒子と思われる。

（２） スラグコンクリートのポップアウトは，スラグ 
中に含まれている遊離の $\mathrm{MgO}$ を主な組成とする粒がコ ンクリート中で水和して $\mathrm{Mg}(\mathrm{OH})_{2}$ に変化する際の体積 膨張によって生じる.

（３） スラグコンクリートのポップアウトは，（2） の理由によって生じるため, コンクリートがしばしば湿 潤される環境下において発生しやすい。 また，乾燥され ない条件下では, 温度が高いほゼ早期に発生する。

（4）遊離の $\mathrm{MgO}$ は，スラグが溶融状態にあるとき に存在しており, その大部分は水砕処理の過程で安定な 水和物に変化すると考えられる. このため, 急冷過程で 水と接触することのない風砕スラグの場合には，ポップ アウトを発生させる粒子が含まれている可能性がきわめ て高い，一方，水砕スラグであっても，水砕後にすべて の遊離の $\mathrm{MgO}$ が水和する以前に水槽中に放出冷却され るものの場合には，一部の $\mathrm{MgO}$ が遊離したまま残存す
るおそれがある.

謝辞：本研究の粉末 X線回折試験を行うにあたつ ては, 筑波大学化学系の中井 泉講師をはじめ同学系分 析研究室の方々にいろいろとご教示を頂いた。 また，本 研究をまとめる際には，同大学物質工学系の永長久彦助 教授に貴重なご助言を賜った。ここに，厚く御礼申し上 げます。

\section{参 考 文 献}

1）秋山 淳・山本泰彦：コンクリート用細骨材としての フェロニッケルスラグの利用, 土木学会論文集, 第 366 号 $/ \mathrm{V}-4, \mathrm{pp} .103 \sim 112,1986$ 年 2 月.

2）秋山 淳・山本泰彦：フェロニッケルスラグのアルカリ シリカ反応性, 土木学会論文集, 第 378 号 / V -6, pp. $157 \sim 163,1987$ 年 2 月.

(1987.6.26 - 受付) 